\title{
The Experimental Behavior Researches of the Reinforced Concrete Beams Bending Stressed By Short - Time Load
}

\author{
Prof.dr Vladimir Radojičić
}

\begin{abstract}
ABSTARCT
Through experimental testing, of series of concrete beams, the author wanted to obtain the tension values in the reinforcement and concrete under the simultaneous load; the occurrence of first cracks and monitoring of their development until the break of the beam and the measured values compared to the calculated ones with the purpose of more realistic analysis and unprovement of the existing theory for calculating the reinforced concrete constructions.
\end{abstract}

Aim: The contribution, although slight, to the theory of the constructions calculation made of the reinforced concrete to be economically payable.

Key words: short-time load, cracks, fracture, mineral fibers, transversal force.

\section{INTRODUCTION}

The behavior of the reinforced concrete beams bending stressed was the topic of many experimental researches up to date. The author's attitude is to describe the behavior of the liner systems at the influence of the transversal forces loaded up to cracking. All that should be done concerning his own experiments and their analysis. The importance of these researches is very big not only for the theoretical analysis of the construction behavior but for possible questions concerning the economical justification of the material use for the concrete making as well. The rational became not only the obligation but the imperative as well.

\section{THE RESEARCH PROJECT}

The two sets of the reinforced concrete beams were tested. One beam set was reinforced by the smooth armature (fig. 1) of the vertical, oblique and vertical oblique stirrups bending stressed up to the cracking.
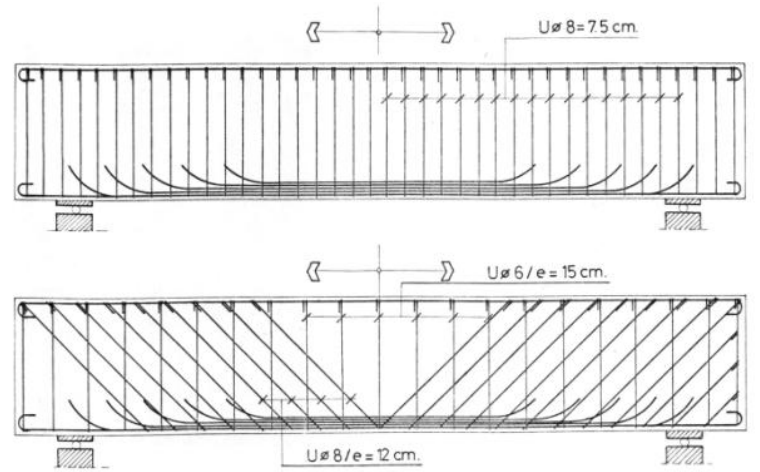

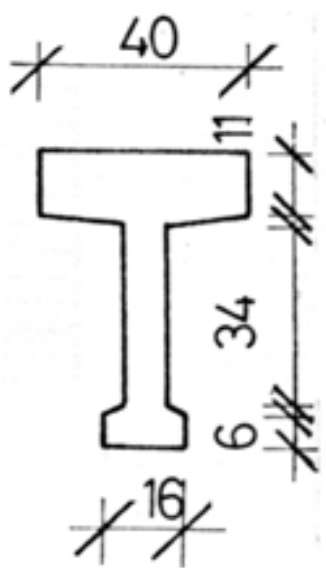

Fig.1 The way of the beam reinforcement

The other beam set was reinforced without any stirrups whose armature was for the bending moment of a force acceptance but not for transversal force acceptance. It was used as a reper of the gauging beams.

The beams of both sets were made according to the concrete mix design (MB 40) with three fractions and with the cement with the addition of the slug (PC 20-45).

After making the beams all at them were exposed to steam curing for 6 hours. After that activity all the beams were intensively wetted for 3 days. All the beams short-time loaded by the contracted force in $1 / 2$ beam up to the cracking.

\section{THE RESEARCHES RESULTS}

The paper presents the load that provokes the cracking, the blow holes and the process of their appearance under the load enlargement. The first cracks on the beam (fig.2) appeared at the force of $373,0 \mathrm{kN}$. This force was 22,295\% bigger 
than the experimental load. The hole on the left crack was $0,05 \mathrm{~mm}$ and on the right crack it was $0,08 \mathrm{~mm}$. the cracks on the rest of the beams appeared to the rest of the beams appeared at the force of $305 \mathrm{kN}$ i.e. $\sigma a=4,211 \mathrm{Mpa}$ (fig.3) at shearing stress. The force bigger $68,205 \%$ than the working load provoked stress was $\mathrm{G}=5,073 \mathrm{MPa}$ when the first cracks appeared in the neutral level. The stress in the oblique stirrup in the middle third of the range at the force of $495 \mathrm{kN}$ was: in the lower area i.e. in the middle part it was $217,5 \mathrm{MPa}$ and in the neutral level it was $214,2 \mathrm{MPa}$; in the upper area it was $210,69 \mathrm{kN}$.

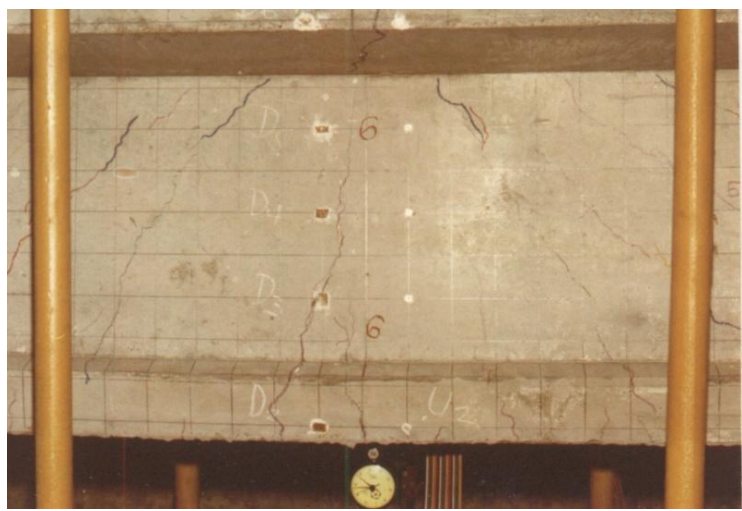

Fig.2 First cracks

In this load period some concrete cracks appeared. The stress values in the stirrups were as follows: $211,3 \mathrm{MPa}$ in the middle stirrup.

$\sigma_{17}=148,05 \mathrm{Mpa}$ in the oblique stirrup

$\sigma_{87}=173,42 \mathrm{Mpa}$ in the oblique stirrup

$\sigma_{19}=54,3 \mathrm{Mpa}$ in the oblique stirrup

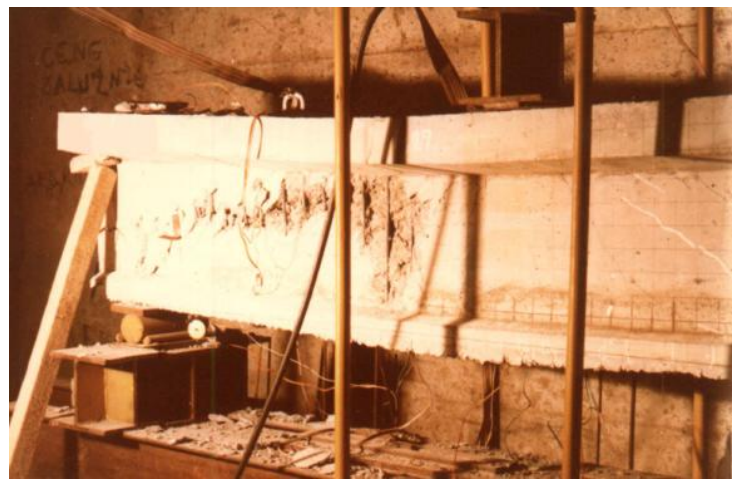

Fig.3 The cracking of the beam

Some cracks appeared between the measured places (i.e. the pressure) and in the middle part of the beams at this stress. The calculation stress in the horizontal armature for the exploitation load was $\sigma a=209,311 \mathrm{Mpa}$ and it was $\sigma a=205,3 \mathrm{Mpa}$ according to the limited state.

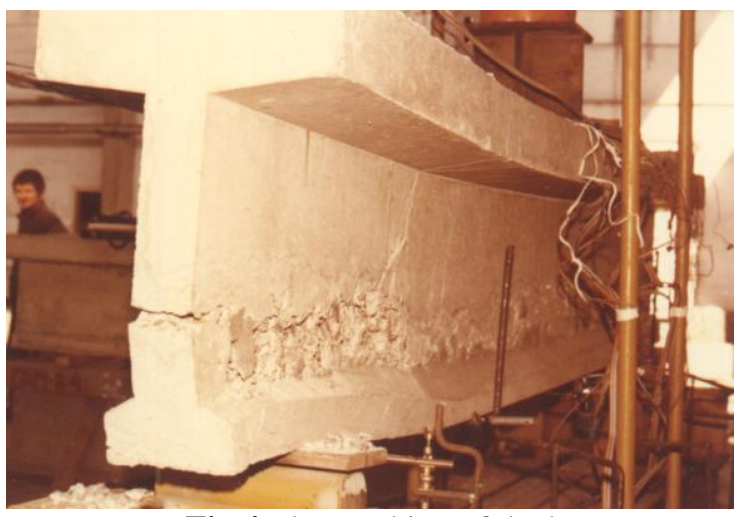

Fig.4 The cracking of the beam

The calculation stress in the stirrups

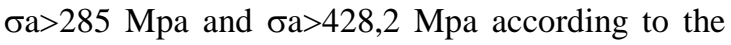
limited state. The cracks appeared in the beams at the force of $615 \mathrm{kN}$. The maximum transversal force was $\mathrm{Q}=310,25 \mathrm{kN}$. The measured stress in the armature for the bending moment acceptance was bigger in the rib than in the armature of the expended lower foot. The measured stress in the tensed armature for the operation load was $\sigma a>153,41 \mathrm{Mpa}$. The middle value of the measured stress in the armature was less than the calculation.

\section{CONCLUSION}

In reference to the analysis of the performed tests, the first cracks appeared.

- in inadequately mortared standard beams, reinforced with smooth reinforcement,

- in beams reinforced with reinforcement for the reception of the principal tension, stress, under tensions whose values ranged from

- The appearance of the first cracks depends on the concrete nurturing concrete quality. Their development depends on the methods of the reinforcing concrete.

- For short-time, before the first cracks, linear elements of the reinforced concrete behave elastifically.

- Measured tension in the armature for the reception of the principal tensions stress is below the tensions obtained by the limit states theory for the exploitation load.

- By increasing the load, the width and length of cracks increased, the compressed zone of concrete decreased, while the level arm of the internal forces increased.

The beam during the first cracks and increase of load began to behave like a bow with the grappling .

- Break force depended on the built of the quality used concrete. 
- In beams, where the built in process was low grade, a premature break appeared at the junction of the lower rib flange.

- In beams with "T" intersection, the panel positioned above the neutral line, it does not participate in the transfer in the transfer of the normal compressive tension.

- Safety factor should be adopted depending on the load, functional conditions of the structure, the state of tensions and the cross section.

- It is necessary to check carefully the quality of steel for the reinforced concrete.

\section{REFERENCES}

[1]. Аћић М., Паквор Ж., Перишић Ж.: Прорачун бетонских и армиранобетонских пресека према допуштеним напонима. Збирка решених задатака, Грађевински факултет, Београд.

[2]. Радојичић Т: Бетонске конструкције I део , Грађевински факултет Ниш, 1981.

[3]. Ивковић М., Радојичић Т: Реологија и општа теорија лома бетона, Научна књига, Београд, 1987.

[4]. Ивковић М., Радојичић Т., Аћић М: Гранична стања бетонских конструкција, Научна књига и Грађевински факултет, Београд, 1986.

[5]. Al-Manaseer, Dalal T.: Concrete Containing plastic Aggregatis, Concrete International, 1997.

[6]. В. Радојичић: Савијање гредних носача од висококвалитетног бетона попречним силама. Докторска дисертација. Ниш, Грађевински факултет Ниш, 2000. године.

[7]. Божиловић С., Чолић П.: Бетонске конструкције, Факултет за грађевински менаџмент "Унион", Београд 2007.

[8]. Стаменковић Х.: Иновације код прорачуна смицања - дијагонални лом код армираног бетона, превод са енглеског, 2002.

[9]. Ристовски А., Радојичић В.: Збирка задатака

[10]. Грдић 3., Топличић Г.: Утицај врсте линеарног дробљеног агрегата на чврстоћу при притиску, Грађевинарство, Наука и пракса, Грађевински факултет, Жабљак 2008.

[11]. Топличић Г., Грдић 3.: Утицај различитих врста дробљених линеарних агрегата на чврстоћу при притиску бетона, мерено склерометром, Зборник радова, симпозијум 2008.

[12]. Грдић 3., Топличић Г., Ристић Н.: Properties of self compacting aggregate, Construction and building materials, article No. 1946, 2010. 